S. BOŻENA SZEWCZUL WNO

Wydział Prawa Kanonicznego

Uniwersytetu Kardynała Stefana Wyszyńskiego w Warszawie

ORCID: 0000-0003-1213-9088

\title{
ZNACZENIE NADZWYCZAJNYCH KAPITUŁ GENERALNYCH W INSTYTUTACH ZAKONNYCH
}

Treść: Wprowadzenie. - 1. Znaczenie kapituł generalnych w historii życia zakonnego. - 1.1. Etymologia wyrazu kapituła. - 1.2. Wpływ kapituły na rozwój życia duchowego mnichów i caritas. - 1.3. Utrzymanie jedności między klasztorami. - 1.4. Poprawa organizacji życia w klasztorze, prowincji i zakonie. - 1.5. Podmiot najwyższej władzy w zakonie - wydawanie norm prawnych. - 1.6. Pojęcie kapituły generalnej. - 2. Kapituła generalna nadzwyczajna. - 3. Cel zwoływania kapituł generalnych nadzwyczajnych po Soborze Watykańskim II. - 4. Zadania kapituły generalnej nadzwyczajnej według Kodeksu Prawa Kanonicznego z 1983 roku. - 4.1. Reprezentacja całego instytutu i prawdziwy znak jego jedności w miłości. - 4.2. Strzeżenie dziedzictwa duchowego instytutu. - 4.3. Popieranie przystosowanej odnowy życia zgodnej z dziedzictwem instytutu. - 4.4. Wybór najwyższego przełożonego. - 4.5. Załatwianie ważniejszych spraw instytutu. 4.6. Wydawanie norm prawnych. - 5. Opinie kanonistów dotyczące kapituł nadzwyczajnych. - Zakończenie.

\section{Wprowadzenie}

Współcześnie w instytutach zakonnych życia konsekrowanego dotkniętych spadkiem liczby powołań, kryzysem sprawowania władzy, formacji członków itd. coraz częściej są zwoływane tzw. kapituły generalne nadzwyczajne poświęcone omówieniu m.in. wymienionych wyżej zagadnień. Od uczestników kapituł oczekuje się znalezienia 
właściwych dróg odnowy życia zakonnego, rozwiązania palących problemów i wyjścia z impasu, a nawet - refundacji instytutu.

Podejmując w niniejszym artykule temat kapituł nadzwyczajnych, trzeba już na wstępie zaznaczyć, że w obowiązującym Kodeksie Prawa Kanonicznego z 1983 roku nie występuje określenie „kapituła generalna nadzwyczajna”. Prawodawca reguluje tylko ogólnie instytucję kapituł generalnych, nie dokonując ani ich podziału na zwyczajne i nadzwyczajne, ani, tym bardziej, nie precyzuje ich kompetencji, ograniczając się do wyliczenia ich ogólnych zadań. Stąd celem podjętego studium jest nakreślenie pojęcia i znaczenia kapituł generalnych w ogóle (gdyż kapituły nadzwyczajne są również kapitułami generalnymi), a w dalszej perspektywie - ukazanie istoty i zadań nadzwyczajnych kapituł generalnych w życiu zakonnym w oparciu o dostępne w literaturze doświadczenie i opinie kanonistów. Wiedza w tym zakresie jest niezbędna, gdyż, jak się wydaje, wielokrotnie przecenia się znaczenie kapituł nadzwyczajnych, zwołuje się je pospiesznie, oczekuje od nich zbyt wiele i traktuje jako skuteczne, bezzwłoczne antidotum na istniejące w życiu zakonnym problemy i wieloletnie zaniedbania, wadliwe decyzje lub ich brak ze strony kompetentnej władzy instytutu.

\section{Znaczenie kapituł generalnych $w$ historii życia zakonnego}

W życiu pierwszych klasztorów monastycznych zasadniczą władzę przypisywano przełożonemu, czyli opatowi klasztoru. W klasztorach benedyktyńskich uważano go za zastępcę Chrystusa, ojca duchowego, pasterza i lekarza dusz, nauczyciela i sędziego. Opat był ojcem, a mnisi jego synami duchowymi, między sobą zaś - braćmi i współsługami ${ }^{1}$.

Od początku istnienia klasztorów reguły monastyczne wyznaczały pewien udział we władzy opata także pozostałym mnichom. Takie współdzielenie władzy przybierało na przestrzeni wieków różne formy - aż do tych o charakterze kolegialnym, nazywanych kapitułami generalnymi. Partycypacja mnichów we władzy realizowała się

\footnotetext{
${ }^{1}$ E. Boaga, Regime. Regime interno, Dizionario degli Istituti di Perfezione, ed. G. Pelliccia-G. Rocca, vol. VII, Roma 1983, col. 1363.
} 
na poziomie konsultacji (decyzyjnym) lub działania ${ }^{2}$. W klasztorach założonych przez św. Pachomiusza (292-346), twórcę życia cenobickiego (klasztornego), spełniała ona także funkcję pojednawczą w przypadku zaistnienia sporu między przełożonym a mnichem lub przy zatrzymaniu przełożonego, który dopuścił się ciężkiego przestępstwa ${ }^{3}$.

W prawodawstwie klasztornym św. Bazylego (329-379) ustanawiano oprócz przełożonego również radę mnichów, zwłaszcza starszych, a także innych mnichów według uznania przełożonego ${ }^{4}$. Również w Regule św. Benedykta z Nursji (480-547) przewidywano jako organ doradczy opata radę starszych oraz całą wspólnotę klasztorną, która bardzo przypomina późniejszą kapitułę ${ }^{5}$.

Wraz ze wzrostem liczby klasztorów, zwłaszcza benedyktyńskich, bo z nimi wiążą się początki kapituły generalnej sensu stricto, dostrzega się dążenie do pewnej formy centralizacji wspólnoty klasztorów należących do tej samej obserwancji, jak np. opactwo Cluny, mimo jednoczesnej niezależności poszczególnych klasztorów i posiadania przez ich opatów pełnej autonomii w zarządzaniu ${ }^{6}$. Łączenie się klasztorów ze sobą sprawiało, że powstawały w konsekwencji odpowiednie organy zarządu centralnego zaistniałej struktury, takie jak kapituła generalna i urząd opata generalnego, którym przyznawano większą lub mniejszą władzę nad pozostałymi opatami, klasztorami i poszczególnymi mnichami. W XII wieku, ze względu na duże odległości geograficzne między wciąż powstającymi klasztorami, doszło do utworzenia mniejszych jednostek, tzw. prowincji jednego zakonu, obejmujących klasztory poszczególnych regionów ${ }^{7}$. Mnisi danej prowincji mogli wysyłać na kapitułę prowincjalną swoich przedstawicieli,

\footnotetext{
${ }^{2}$ Tamże.
}

${ }^{3}$ Tamże.

4 Tamże.

${ }^{5}$ Tamże, col. 1364; Benedykt z Nursji, Reguła, (przekład A. Świderkówna), Tyniec 1997, nr 3.

${ }^{6}$ M. Antalóczy, Il capitolo generale nell'Ordine Frati Predicatori agli inizi ed oggi. Comparazione storico-giuridica, Rome 1996, s. 20.

${ }^{7}$ E. BoAgA, Regime. Regime interno, col. 1366. 
zapewniając sobie tym samym udział w kapitule i wywierając wpływ na podejmowane tam decyzje ${ }^{8}$.

\subsection{Etymologia wyrazu kapituła}

Etymologicznie polski termin kapituła pochodzi od łacińskiego słowa capitulum, które oznacza zdanie, rozdział, fragment jakiegoś pisma lub książki, także Pisma Świętego9. W życiu monastycznym słowo capitulum jako oznaczające część książki odnosiło się początkowo do passusu reguły zakonnej, mającej kształt książki opisującej sposób życia mnichów, do którego zobowiązywali się oni przez złożenie ślubu posłuszeństwa i conversatio morum ${ }^{10}$. W klasztorach benedyktyńskich istniał zwyczaj czytania capitulum Reguły każdego ranka po recytacji Pierwszej Godziny Liturgii godzin. Następnie określeniem tym objęto całą wspólnotę, w której czytano capitulum, czas czytania, samo spotkanie mnichów w trakcie odczytu oraz miejsce w klasztorze (kapitularz), gdzie odbywała się lektura ${ }^{11}$.

\subsection{Wpływ kapituły na rozwój życia duchowego mnichów i caritas}

Zebrania wszystkich mnichów przynależących do jednego klasztoru i spotykających się codziennie w ramach kapituł miały wymiar przede wszystkim duchowy, ponieważ taki charakter miała właśnie

${ }^{8}$ G. Rocca, Regime, III. Questioni particolari, Dizionario degli Istituti di Perfezione, ed. G. Pelliccia-G. Rocca, vol. VII, Roma 1983, s. 1392.

${ }^{9}$ A. Jougan, Słownik kościelny łacińsko-polski, Warszawa 1992³ , s. 90; J. SondeL Słownik łacińsko-polski dla prawników i historyków, Kraków 1997, s. 129; G.P. MoNTINI, Il diritto canonico dalla A alla Z: C. Capitolo, Quaderni di Diritto Ecclesiale 6(1993), s. 108-109; B. Szewczul, Troska Kościoła o zachowanie "patrimonium» przez instytuty życia konsekrowanego na podstawie dokumentów kościelnych z lat 1917-1996, Warszawa 2002, s. 294-295.

${ }^{10}$ Benedy k z zursji, Reguła, nr 58: „Ten, który ma być przyjęty, w oratorium w obecności wszystkich złoży przyrzeczenie stałości, zachowania obyczajów monastycznych i posłuszeństwa. [A złoży je] przed Bogiem i Jego Świętymi”.

${ }^{11}$ G.P. Montini, Il diritto canonico dalla A alla Z, s. 114-115; G. LesAGe, Capitolo, Dizionario degli Istituti di Perfezione, ed. G. Pelliccia-G. Rocca, vol. II, Roma 1975, col. 166; F. IANNONE, Il capitolo generale. Saggio storico-giuridico, Roma 1988, s. 25; J. Torres, I capitoli. Commentario ai cann. 631-633, Roma 1996-1997, s. 5. 
czytana Reguła np. św. Benedykta z Nursji. Ukazywała ona sposób podążania „ścieżkami Pana za przewodem Ewangelii” dla osiągnięcia świętości ${ }^{12}$. Już poczynając od prologu Reguły, wciąż można napotkać przytaczane w niej słowa Pisma Świętego. A skoro tak, to każdy mnich musiał znać Regułę, a ignorancja w tej kwestii nie mogła być usprawiedliwiona ${ }^{13}$. Dodatkowo opat klasztoru wyjaśniał mnichom przeczytany fragment Reguły, a mnisi włączali się do dyskusji. Czytanie Reguły służyło mnichom pomocą w dokonywaniu każdego dnia konfrontacji swoich poczynań z jej treścią i w coraz doskonalszym dostosowywaniu własnego sposobu życia do tego ukazanego w Piśmie Świętym a opisanego w regułach przez pierwszych zakonodawców ${ }^{14}$. Niektórzy autorzy dopatrują się źródeł kapituł generalnych bezpośrednio w niektórych perykopach ewangelicznych ${ }^{15}$.

Także na Wschodzie spotkania wszystkich mnichów należących do klasztorów założonych przez św. Pachomiusza, bardzo przypominających współczesne kapituły generalne ze względu na pełną reprezentację zakonu, odbywały się dwa razy w roku. Pierwsze spotkanie, właśnie to o charakterze wybitnie duchowym, organizowano w czasie Wielkanocy dla celebracji świętych misteriów Paschy i Chrztu Świętego. Kapituły te sprzyjały jedności braci i wzmocnieniu miłości

\footnotetext{
${ }^{12}$ Benedykt z Nursji, Reguła, prolog 21.

13 Tenże, Reguła, nr 66: „Chcemy też, by ta Reguła często była czytywana we wspólnocie, aby żaden brat nie mógł się tłumaczyć jej nieznajomością”.

${ }^{14}$ F. IAnnone, Il capitolo generale. Saggio storico-giuridico, s. 25.

${ }^{15}$ Por. P. s. Moffett, Viewing Chapters as «Authoring» Our Congregations' Narratives, Review for Religious 63 (2004), s. 172. P. s. Moffett wskazuje w tym miejscu na kilka emblematycznych perykop Nowego Testamentu, m.in. przemienienie Pana Jezusa, Ostatnia Wieczerza oraz opisy spotkania uczniów ze Zmartwychwstałym. Amerykański teolog zauważa, że w każdym w powyższych fragmentów centralne miejsce zajmuje osoba Jezusa. Zgromadzeni wokół Niego uczniowie, którzy wcześniej dokonali już osobistej decyzji pójścia za Nim, zbierają się, by dokonać rewizji dotychczasowej drogi oraz usłyszeć od swojego Mistrza nowe wyzwania, przed którymi stają w danym momencie. W ten sposób wspólne zebranie Jezusa z uczniami staje się źródłem nadziei, pomimo zewnętrznych przeciwności oraz zdrady i niewierności ze strony powołanych, z jakimi musieli zmierzyć się w realizacji powierzonej im wcześniej misji.
} 
bliźniego (caritas) ${ }^{16}$. Duże znaczenie dla rozwoju życia duchowego mnichów miał również inny rodzaj spotkań $\mathrm{w}$ formie kapituł w obrębie jednego klasztoru - tzw. kapituły win ${ }^{17}$. Także w późniejszych wiekach, kiedy kapituły przedstawicieli wielu klasztorów stały się organem władzy generalnej zakonu, stawiały sobie one nadal cele duchowe, jak np. przedyskutowanie sprawy reformy zakonu oraz przestrzegania Reguły, do czego zachęcały postanowienia Soboru Laterańskiego $\mathrm{IV}^{18}$.

\subsection{Utrzymanie jedności między klasztorami}

Wprowadzenie nowego modelu sprawowania władzy w sposób scentralizowany w klasztorach w XII w. sprawiło, że zmieniła się koncepcja kapituły generalnej. Centralizacja władzy w klasztorze Cluny oraz Cîteaux doprowadziła do przejęcia przez regularnie zwoływane kapituły generalne jeszcze jednego zadania - troski o utrzymanie jedności między poszczególnymi klasztorami ${ }^{19}$.

\footnotetext{
${ }^{16}$ Por. W.F. Hogan, Evolution in Chapters, Review for Religious 35 (1976), s. 46; G. Lesage, Capitolo, col. 166; J. Gribomont, Pacomio, Dizionario degli Istituti di Perfezione, ed. G. Pelliccia-G. Rocca, vol. VI, Roma 1980, col. 1070; E. BoAGA, Regime. Regime interno, col. 1363; C. Girgoud, L'Orde des Chanoines réguliers de Saint-Augustin et ses diverses forms de régime interne, Martigny 1961, s. 131.

${ }^{17}$ Kapituła win odbywała się w sali kapitulnej. W czasie jej trwania wszyscy mnisi oskarżali się przed całą wspólnotą z własnych braków, publicznych win popełnionych przeciwko regule. W czasie tego spotkania recytowano psalmy, czytano Pismo Święte, a więc było to wydarzenie o charakterze duchowym. P. Lippini, La vita quotidiana di un convento medievale, gli ambienti, le regole, l'orario e le mansioni dei Frati Domenicani del tredicesimo secolo, Bologna 2008, s. 351-355.

${ }^{18}$ Sobór LATERAŃski IV (1215), Konstytucja 12. w: Dokumenty soborów powszechnych. Tekst grecki, łaciński, polski, t. II (869-1312) (oprac. A. Baron, H. Pietras), Kraków 2003, s. 248-251; M. Antalóczy, Il capitolo generale nell'Ordine Frati Predicatori agli inizi ed oggi, s. 29; M. DANILUK, Encyklopedia instytutów życia konsekrowanego i stowarzyszeń życia apostolskiego, Lublin 2000, s. 171.

${ }^{19}$ Por. E. McDonough, General Chapters: Historical Background, Review for Religious 55 (1996), s. 321-322.
} 
Celem kapituł cystersów według Carty Caritatis było zapewnienie zachowania jedności między autonomicznymi klasztorami ${ }^{20}$, czyli, innymi słowy, zapewnienia jedności i zachowania równowagi między rządzonymi i rządzącymi oraz - z jednej strony - centralizacji, zaś z drugiej - zachowania autonomii klasztorów ${ }^{21}$.

\subsection{Poprawa organizacji życia w klasztorze, prowincji i zakonie}

$Z$ biegiem czasu można było zauważyć, że pierwsze kapituły mnichów przysłużyły się także do lepszej organizacji życia klasztornego. Opat na zakończenie rannej kapituły wyznaczał podwładnym prace do wykonania na dany dzień. Spotkania kapituły były także okazją do rozpatrywania ważniejszych spraw klasztoru i podejmowania decyzji - opat wysłuchiwał zdania wszystkich mnichów w danej sprawie, także tych najmłodszych, a następnie podejmował decyzję ${ }^{22}$. W czasie zebrań kapituł dokonywano również wyboru opata klasztoru ${ }^{23}$.

Także mnisi przynależący do klasztorów św. Pachomiusza drugie roczne spotkanie wszystkich członków zakonu w Pabau w sierpniu poświęcali sprawom administrowania dobrami materialnymi według motta „jasne układy - przyjaźń długa”. Każdy przełożony klasztoru był zobowiązany do przedłożenia sprawozdania z warunków życia podległej mu wspólnoty. Poza tym wyznaczano w tym czasie nowych przełożonych poszczególnych klasztorów ${ }^{24}$.

\footnotetext{
${ }^{20}$ M. Antalóczy, Il capitolo generale nell'Ordine Frati Predicatori agli inizi ed oggi, s. 22; Por. E. McDonough, General Chapters, s. 321-322.

${ }^{21}$ E. Boaga, Regime. Regime interno, col. 1366.

${ }^{22}$ Benedy kt z Nursji, Reguła, nr 3; G.P. Montini, Il diritto canonico dalla A alla $Z$, s. 114 .

${ }^{23}$ Benedy kt z Nursji, Reguła, nr 64; G.P. Montini, Il diritto canonico dalla A alla Z, s. 114; E. BoAgA, Regime. Regime interno, col. 1364.

${ }^{24}$ Por. W.F. Hogan, Evolution in Chapters, Review for Religious 35 (1976), s. 46. G. Lesage, Capitolo, col. 166; J. Gribomont, Pacomio, col. 1070; E. Boaga, Regime. Regime interno, col. 1363.
} 


\subsection{Podmiot najwyższej władzy w zakonie - wydawanie norm prawnych}

Kapituły, jak już wyżej wspomniano, były w swych początkach zebraniami wspólnoty danego klasztoru, a następnie, w drodze rozwoju, przekształciły się z lokalnego narzędzia konsultacji i uczestnictwa w posłudze sprawowania władzy opata w organ składający się z przedstawicieli całego zakonu ${ }^{25}$. Służyły utrzymaniu wzajemnych relacji między klasztorami i stały się kapitułami z uczestnictwem opatów i przełożonych klasztorów ${ }^{26}$. Klasztory zgromadzone wokół Cluny utrzymały okresowe zebrania reprezentantów wszystkich klasztorów dla umocnienia caritas i omówienia wspólnych spraw ${ }^{27}$. Klasztory filialne związane z klasztorem w Cluny utworzyły pewną strukturę scentralizowaną i podporządkowaną opatowi klasztoru macierzystego, z którego wzięły swój początek. Jemu powierzano władzę zarządu i kontroli nad wszystkimi klasztorami, tj. około 2000 obiektów. W praktyce jednak okazało się to niełatwe i praktycznie niemożliwe ze względu na ówczesne trudności komunikacyjne, dlatego system centralizacji władzy w ręku jednego opata szybko zmienił się i został zastąpiony przez kapitułę opatów, jak nieco później, w przypadku zakonu cystersów związanych z klasztorem w Citeaux ${ }^{28}$. Chociaż kapituły tego typu pierwszych dziesięciu wieków w historii życia zakonnego bardzo przypominały współczesną kapitułę generalną, to jednak wciąż nie były one uważane za podmiot władzy ${ }^{29}$.

\footnotetext{
${ }^{25}$ M. Cotter, The General Chapter in a Religious Institute wih Paticular Reference to IBVM Loreto Branch, Bern 2008, s. 25.

${ }^{26}$ V. De PAOLIs, La vita consacrata nella Chiesa. Edizione rivista e ampliata a cura di Vincenzo Mosca, Venezia 2011, s. 384.

${ }^{27}$ L.G. Martín, Capitolo. Aspetti giuridici, w: Dizionario Teologico della Vita Consacrata, dir. A.A. Rodríguez, J.M. Canals Casas, Milano 1994, s. 166; J. GriboMONT, Pacomio, col. 1070.

${ }^{28}$ J. Torres, I capitoli. Commentario ai cann. 631-633, Roma 1996-1997, s. 6; J. Leclerce, Cluniacensi, Dizionario degli Istituti di Perfezione, ed. G. Pelliccia-G. Rocca, vol. II, Roma 1975, col. 1198-1200; A. Dimier, Citeaux, Dizionario degli Istituti di Perfezione, ed. G. Pelliccia-G. Rocca, vol. II, Roma 1975, col. 1107-1108.

${ }^{29}$ L. Gutiérrez Martín, Capitolo. Aspetti giuridici, s. 166; G. Lesage, Capitolo, col. 166.
} 
Podstawy prawne kapitule generalnej w pełnym tego słowa znaczeniu dała Charta caritatis z 1119 r., czyli konstytucja zakonu cystersów zredagowana przez św. Stefana Hardinga, trzeciego opata klasztoru w Citeaux, zatwierdzona w tym samym roku przez papieża Kaliksta II ${ }^{30}$. W Charta caritatis postanawiano zwoływać coroczne kapituły określane mianem generalnych ${ }^{31} \mathrm{z}$ udziałem wszystkich opatów bez wyjątku. Jedyną okolicznością usprawiedliwiającą nieobecność w obradach kapituły był stan zdrowia opata. Celem spotkań było sprawdzenie zachowywania Reguły oraz przeprowadzenie kontroli klasztorów. Kapituła rozpatrywała również sprawy sporne między opatami, a także inne kwestie dotyczące zakonu, takie, jak założenie nowych fundacji klasztornych, a także problemy liturgiczne i formacyjne ${ }^{32}$. Władzy kapituł generalnych pozostawiano również mianowanie opatów poszczególnych klasztorów i innych ważniejszych urzędów, np. przełożonych, magistrów nowicjatu, a także przenoszenie mnichów z jednego do drugiego klasztoru ${ }^{33}$.

\footnotetext{
${ }^{30}$ Calixtus II, Ad Stephanum abbatem Cisterciensem, w: J.D. Mansi, Sacrorum conciliorum amplissima collectio, 2nd ed., vol. 21, Paris 1901, s. 190-191: „Nos ergo in Domino profectui conaudentes, capitula illa et constitutiones auctoritate apostolica confirmamus et omnia in perpetuum rata permanere decernimus"; J. TURK, Textus Chartae Caritatis Posterioris, Analecta Sacri Ordinis Cisterciensis 1(1945), s. 47-61; E.M. Cotter, The General Chapter, s. 21-22; M. Antalóczy, Il capitolo generale nell'Ordine Frati Predicatori agli inizi ed oggi, s. 21.

${ }^{31}$ J. Torres, I capitoli. Commentario ai cann. 631-633, s. 5.

${ }^{32}$ G. Lew Is, Chapters in Religious Institutes: An Historical Synopsis and Commentary, Canon Law Studies, no. 181, Washington 1943, s. 20; E.M. CotTER, The General Chapter, s. 21-22. [Do tej myśli autorka dodaje następujący przypis: In the decree of confirmation, Pope Calixtus II made specific reference to the chapter: „Nos ergo in Domino profectui conaudentes, capitula illa et constitutiones auctoritate apostolica confirmamus et omnia in perpetuum rata permanere decernimus" (Calixtus II, Ad Stephanum abbatem Cisterciensem, in J.D. Mansi, Sacrorum conciliorum amplissima collectio, 2nd ed., vol. 21, Paris 1901, s. 190-191]. Szczegółowe opracowanie zagadnienia kapituły generalnej w pierwszych wiekach chrześcijaństwa w: F. IANNONE, Il capitolo generale: Origine e sviluppo storico. Legislazione del C.J.C. del 1983, Roma 1988, s. 26-34.
}

${ }^{33}$ E. BoAgA, Regime. Regime interno, col. 1366. 
Instytucja kapituł generalnych pojawia się w powszechnym ustawodawstwie kościelnym po raz pierwszy w czasie Soboru Laterańskiego IV (1215 r.). Jednym z efektów obrad soborowych było zalecenie, aby co trzy lata zbierały się kapituły opatów i przeorów danego królestwa lub prowincji, celem przedyskutowania sprawy reformy zakonu oraz przestrzegania Reguły. W czasie trwania kapituły pobożni ludzie udawali się do klasztorów danego królestwa lub prowincji, gdzie odbywała się kapituła, celem karcenia i reformowania tego, co wymagało skarcenia i zreformowania. Ich zadaniem było też wydawanie decyzji w sprawie ewentualnego usunięcia przełożonego z urzędu ${ }^{34}$. Przez długi czas kapituły skupiały w swoim składzie jedynie opatów klasztorów. Początkowo działające w sposób zdyscyplinowany, z czasem kapituły były jednak coraz rzadziej zwoływane, okres ich obrad - skracany, a opaci daleko położonych klasztorów korzystali $\mathrm{z}$ dyspensy $\mathrm{z}$ uczestnictwa za odpowiednią opłatą ${ }^{35}$. Zalecenia Soboru Laterańskiego dotyczące kapituł generalnych zostało zamieszczone następnie w Dekretałach Grzegorza IX ${ }^{36}$.

W wieku XIII powstające zakony żebrzące o organizacji centralnej (przełożony generalny sprawował władzę na wszystkimi klasztorami i zakonnikami) przyjęły kapitułę jako formę zarządu zakonem. Struktura podziału zakonu przewidywała trzy poziomy władzy przełożonych: generalny, prowincjalny i lokalny. Sprawowanie władzy przez poszczególnych przełożonych, odpowiednio, nad całym zakonem, prowincją i konwentem, domagało się konsultacji braterskiej i podjęcia niektórych decyzji w sposób kolegialny. Z tej właśnie potrzeby

\footnotetext{
34 Sobór Laterański IV (1215), Konstytucja 12. w: Dokumenty soborów powszechnych. Tekst grecki, łaciński, polski, t. II (869-1312) (oprac. A. Baron, H. Pietras), Kraków 2003, s. 248-251; M. Antalóczy, Il capitolo generale nell'Ordine Frati Predicatori agli inizi ed oggi, s. 29; Por. L. Gutiérrez Martín, Capitolo. Aspetti giuridici, s. 166-167).

${ }^{35}$ L. Moulin, Vita e governo degli ordini religiosi, Milano 1965, s. 278-279: „Dal 1584 al 1765 furono tenute 15 sedute, mentre all'inizio esse erano state annuali. Nel XVIII secolo, secolo di crisi, se mai ce n'è stato uno, il Capitolo si riunì solo due volte".

${ }^{36}$ X, De statu Monachorum, III, 35, c.7.
} 
wyrósł organ centralny, kolegialny w postaci kapituły generalnej (obok kapituł prowincjalnych i lokalnych) ${ }^{37}$. Kapituła generalna miała władzę także nad przełożonym generalnym, z możliwością usunięcia go $\mathrm{z}$ urzędu ${ }^{38}$. Przeciwko rodzącej się ideologii parlamentarnej w życiu zakonnym wystąpił nowy zakon - Towarzystwo Jezusowe - założony przez św. Ignacego Loyolę. Przyjęto w nim zarząd monarchiczny przełożonego generalnego przy udziale kongregacji generalnej, której zarezerwowano pełnię władzy ustawodawczej, choć nie mogła ona ustanawiać żadnych praw przed wyborem przełożonego generalnego ${ }^{39}$.

Na Soborze Trydenckim powrócono do zagadnienia kapituł generalnych, nadal zalecając ich zwoływanie i podkreślając ich istotną rolę ${ }^{40}$.

Powstające w kolejnych wiekach zgromadzania zakonne o ślubach prostych przejęły instytucję kapituł generalnych jako organu swej najwyższej władzy, a normy prawne co do sposobu ich funkcjonowania wydała w 1901 r. Święta Kongregacja Biskupów i Zakonników ${ }^{41}$.

\footnotetext{
${ }^{37}$ Franciszen z Asyżu, Reguła zatwierdzona, rozdz. 8, w: Pisma św. Franciszka z Asyżu, Warszawa $1990^{3}$, s. 95; F. IANnONE, Il capitolo generale. Saggio storico-giuridico, Roma 1988, s. 34-36; G. SCARVAGLIERI, Il Capitolo generale. Preparazione, celebrazione, attuazione, Milano 2002, s. 21.

${ }^{38}$ M. DANILUK, Encyklopedia instytutów życia konsekrowanego i stowarzyszeń życia apostolskiego, s. 171.

${ }^{39}$ J. Torres, I capitoli. Commentario ai cann. 631-633, s. 7.

${ }^{40}$ Por. Sobór Trydencki, Sesja XXV, Dekret w prawie zakonników izakonnic, rozdział VIII, Zasady postępowania z klasztorami, które nie mają swoich zwyczajnych wizytatorów, w: Dokumenty soborów powszechnych. Tekst łaciński i polski, t. IV (1511-1870), (oprac. A. Baron, H. Pietras), Kraków 2005, s. 792-795.

${ }^{41}$ Sacra Congregatio Episcoporum et Regularium, Normae, secundum quas S. Congr. Episcoporum et Regularium procedere solet in approbandis novis institutis votorum simplicium, 28 iunii 1901, w: T. SCHAEFER, De religiosis ad normam Codicis Iuris Canonici, Roma 19474, s. 1102-1134; także w: E. SAstre Santos, El ordenamiento de los institutos de votos simples según las Normae de la Santa Sede (1854-1958), Roma-Madrid 1993, Apéndice documental, nr 57, s. 266-299 (dalej: Normy); M. DANILUK, Encyklopedia instytutów życia konsekrowanego i stowarzyszeń życia apostolskiego, s. 171.
} 
Normy podają, że władza najwyższa w instytucie jest sprawowana w sposób zwyczajny przez najwyższego przełożonego wraz z jego radą oraz w sposób nadzwyczajny -przez kapitułę generalną. W Kodeksie z 1917 r. potwierdza się konieczność istnienia kapituł, które wraz z przełożonymi sprawują władzę nad podwładnymi (kan. 501 \$1, 507 $\$ 1 \mathrm{KPK} / 1917)$ i nie wnosi się dodatkowych uregulowań, innych niż te zawarte w Normach ${ }^{42}$.

Kapituły cystersów według Charta caritatis miały uprawnienia legislacyjne i wydawały decyzje w formie norm prawnych, obligujących wszystkich mnichów do ich zachowania. Normy te były zamieszczane w zbiorze Instituta Generalis Capituli ${ }^{43}$.

Badając historię powstania i rozwoju kapituł generalnych trzeba podkreślić, że od swoich początków były one organem wymagającym uczestnictwa pośrednio wszystkich członków klasztoru, a potem całych zakonów czy instytutów zakonnych życia konsekrowanego ${ }^{44}$.

\subsection{Pojęcie kapituły generalnej}

Pojęcie kapituły generalnej w obowiązującym KPK/1983 zostało uregulowane i doprecyzowane w kan. 631 i częściowo 632, po omówieniu przez prawodawcę we wcześniejszych kanonach zagadnienia władzy przełożonych instytutów zakonnych oraz ich rad, czyli organów, które w sposób zwyczajny sprawują władzę w instytutach. Kapituły generalne są natomiast formą sprawowania władzy w sposób nadzwyczajny ${ }^{45}$.

${ }^{42}$ Normy 201; V. De PAOLIs, La vita consacrata nella chiesa, Bologna 1992, s. 228; J. Torres, I capitoli. Commentario ai cann. 631-633, s. 10-11; F. IANNONE, Il capitolo generale. Saggio storico-giuridico, s. 45.

${ }^{43}$ M. Antalóczy, Il capitolo generale nell'Ordine Frati Predicatori agli inizi ed oggi, s. 21.

${ }^{44}$ V. De Paolis, La vita consacrata nella Chiesa. Edizione rivista e ampliata, s. 385.

${ }^{45}$ G. Scarvaglieri, Il Capitolo generale, s. 28; PAOLIS V. DE, La vita consacrata nella Chiesa, Bologna 1992, s 226. Termin „nadzwyczajny” nie jest odpowiedni dla wyrażenia charakteru władzy kapituły generalnej. Nie został przywołany przez prawodawcę w kanonie, ponieważ, ze względu na swą dwuznaczność, mógłby prowokować nieporozumienia. Władza kapituły generalnej jest bowiem nadzwyczajna 
Z powyższych dociekań wynika, że kapituła generalna to zebranie reprezentujących cały instytut członków danego instytutu, zwoływane w celu załatwiania spraw powierzonych mu przez prawo powszechne i własne. Kapituła jest wobec tego osobą prawną posiadającą w czasie swojego obradowania ${ }^{46}$ najwyższą władzę w instytucie, uprawnioną do wydawania norm prawnych, które są zobowiązani wypełniać wszyscy członkowie instytutu, nie należy jednak do organów stałych, gdyż obraduje tylko przez pewien czas. Posiadanie osobowości prawnej przez kapituły odróżnia je od innych podobnych zebrań w instytutach, tj. organów uczestnictwa i konsultacji, które tej osobowości nie posiadają i nie mają porównywalnej władzy ${ }^{47}$.

Biorąc pod uwagę cel zwoływania kapitul, dzieli się je na: wyborcze, czyli wybierające najwyższego przełożonego i jego radę, kapituły rozpatrujące pilne sprawy instytutu (kapituły spraw) oraz mieszane, które wybierają zarówno przełożonego najwyższego i jego radę jak i rozpatrują ważne sprawy instytutu. Istnieją również kapituły prowincjale, lokalne ${ }^{48}$ (domowe) oraz kapituły win $^{49}$.

w znaczeniu jej periodyczności - kapituła zbiera się w czasie nieokreślonym czasowo, między zwoływaniem kapituł zwyczajnych. $Z$ drugiej jednak strony kapituła nie jest wydarzeniem nadzwyczajnym, przynajmniej kapituła zwyczajna ma władzę własną zwyczajną wtedy, gdy obraduje. Więcej na ten temat: F. Iannone, Potestà del Capitolo Generale (cann. 596; 631, \$1), Commentarium pro Religiosis et Missionariis 68(1987), s. 77-97, 223-244.

${ }^{46} \mathrm{~J}$. WroceńsKi, Kapituła generalna podmiotem najwyższej władzy w instytucie zakonnym, Sympozjum 22(2016) nr 2(31), s. 211-237.

${ }^{47}$ V. De PAOLIS, La vita consacrata nella Chiesa. Edizione rivista e ampliata, s. 383.

${ }^{48} \mathrm{~V}$. Verтн, Il capitolo locale. Esperienze, riflessioni e orientamenti delle fraternità cappucine, n.1, Bologna 1993; G. SCARvaGLIERI, Il Capitolo generale, s. 28-30. Oprócz kapituł generalnych istnieją także kapituły prowincjalne oraz lokalne, w zależności od tego, czy reprezentują prowincję czy np. dom zakonny. J.R. BAR, J. KAŁowsKI, Prawo o instytutach życia konsekrowanego, s. 72; L. Gutiérrez Martín, Capitolo. Aspetti giuridici, s. 165; J. Beyer, Il diritto capitolare, Vita Consacrata 14 (1978), s. $462-471$.

${ }^{49}$ B. SzewCzul, Ascetyczna praktyka kapituly win w instytutach zakonnych, Studia Redemptorystowskie 10(2012), s. 476-485. 
Ze względu na przyczynę zwoływania można wyróżnić kapituły zwyczajne, zwoływane periodycznie, zgodnie z przepisami konstytucji, najczęściej wraz z upływem kadencji najwyższego przełożonego, oraz wzmiankowane w tytule niniejszego studium - kapituły nadzwyczajne.

\section{Kapituła generalna nadzwyczajna}

Kapitułę generalną nadzwyczajną zwołuje się w celu załatwienia ważnych spraw instytutu w okresie między obradowaniem kapituł zwyczajnych $^{50}$.

W Normach wydanych w 1901 r. przez Świętą Kongregację Biskupów i Zakonników i podejmujących temat sposobu postępowania przy zatwierdzaniu nowych instytutów o ślubach prostych pojawiło się po raz pierwszy określenie "kapituła generalna nadzwyczajna” obok terminu "kapituła zwyczajna”, określenie mające na celu nazwanie zebrań zwoływanych po upływie czasu wyznaczonego przez konstytucje instytutu dla pełnienia urzędu przez przełożoną najwyższą $a^{51}$. Wyróżniano dwie przyczyny zwołania tego rodzaju kapituł - z powodu śmierci przełożonej wyższej, rezygnacji lub złożenia jej z urzędu ${ }^{52}$. Kapitułę nadzwyczajną można było zwołać także $\mathrm{z}$ innych przyczyn niż te wymienione $\mathrm{w}$ dokumencie, przy czym

\footnotetext{
${ }^{50}$ V. De Paolis, La vita consacrata nella Chiesa, Bologna 1992, s 226. G. Lesage, Capitolo, col. 174; J. Torres, I capitoli. Commentario ai cann. 631-633, s. 10; G. SCARVAGLIERI, Il Capitolo generale, s. 29-30: „Il capitolo straordinario, come dice lo stesso termine, invece, richiama una celebrazione fuori delle scadenze consuete, e serve quindi a rispondere a bisogni o problemi particolari. Esso ha uguali competenze e autorità, specialmente in vista delle discussione e decisione di argomenti importanti per la situazione in cui dovesse venire a trovarsi un dato istituto”.

${ }^{51}$ Normy, nr 206: „Haec convocatio alia ordinaria est, quae locum habet post elapsum tempus a Constitutionibus pro officio moderatricis statutum;”.

${ }^{52}$ Normy, nr 206: „... alia extraordinaria, quando scilicet propter mortem moderatricis generalis (vel eius resignationem vel depositionem) tempore sui officii sequutam necessaria evadit”.
} 
należało wcześniej uzyskać pozwolenie Świętej Kongregacji Biskupów i Zakonników ${ }^{53}$.

Wraz z wydaniem Norm przez Świętą Kongregację Biskupów i Zakonników w 1901 r. w prawie dotyczącym kapituł generalnych pojawiły się wątpliwości terminologiczne. Kapitułę generalną określono w nich jako funkcjonującą w instytucie najwyższą władzę, która może być sprawowana w sposób zwyczajny przez przełożoną generalną z jej radą, a w sposób nadzwyczajny - przez kapitułę generalną ${ }^{54}$. Często natomiast w konstytucjach niektórych instytutów pojawia się stwierdzenie, że kapituła generalna jest najwyższą władzą nadzwyczajną w opozycji do najwyższej władzy zwyczajnej, jaką miałaby być władza przełożonego generalnego ${ }^{55}$. Po Soborze Watykańskim II w niektórych odnowionych konstytucjach pojawiło się jeszcze jedno określenie dotyczące kapituły generalnej, a mianowicie, że jest ona władzą kolegialną ${ }^{56}$.

${ }^{53}$ Normy, nr 210: „Pro convocando capitulo generali exstraordinario ex alia quacumque causa quam supra (n. 206) indicata, requiritur licentia Sacrae Congregationis".

${ }^{54}$ J. Torres, I capitoli. Commentario ai cann. 631-633, s. 10.

${ }^{55}$ Tamże.

56 Tamże; M. Dortel-Claudot, Le strutture di governo e di partecipazione delle Congregazioni Religiose, Milano 1986, s. 19. Autor wyjaśnia nowe określenie kolegialności w odniesieniu do życia zakonnego. Nie uznaje powszechnej opinii odnoszenia tego terminu do każdego pobożnego uniesienia. Jego zdaniem kolegialny charakter można przypisać jedynie kapitułom generalnym oraz prowincjalnym w granicach ich kompetencji. Tylko one są organem decyzyjnym kolegialnym w sensie ścisłym. O kolegialności świadczy fakt, że wszyscy członkowie kapituły mają te same prawa i władzę. Decyzje są podejmowane w wyniku głosowania, głosy mają jednakową wartość, ciężar, zarówno w odniesieniu do przełożonej generalnej czy prowincjalnej lub zwykłej członkini kapituły: „A mio avvio si può tutt’al più parlare di collegialità a proposito di quell'organo ben particolare che è un Capitolo generale. ...lo stesso dicessi di un Capitolo provinciale, nei limiti della sua competenza... le schede di voto hanno tutte il medesimo peso, lo stesso valore: quella della Superiora generale non pesa più di quella di una qualsiasi altra capitolare. E' un organo di governo, i cui membri agiscono colleggialmente, un organo di governo collegiale in senso stretto". 
J. Beyer w swym komentarzu do KPK/1983 wyjaśnia, odmiennie niż przepisywały to Normy z 1901 r., że kapituła nadzwyczajna jest zwoływana w sytuacjach nadzwyczajnych, natomiast w przypadku śmierci przełożonego generalnego lub innej okoliczności, która nie pozwala mu na sprawowanie władzy w trakcie trwania jego kadencji zwoływana jest kapituła generalna zwyczajna ${ }^{57}$. Również w prawodawstwie własnym instytutów nie ma obecnie jednomyślności w tym względzie - w niektórych z nich kapituła zwoływana w przypadku śmierci przełożonego najwyższego lub w sytuacji, gdy nie może on sprawować władzy jest kapitułą zwyczajną, w innych natomiast kapitułą nadzwyczajną ${ }^{58}$.

\section{Cel zwoływania kapituł generalnych nadzwyczajnych po Soborze Watykańskim II}

Po zakończeniu Soboru Watykańskiego II papież Paweł VI zalecił instytutom zakonnym zwołanie w ciągu dwóch lub trzech lat od wydanego przez siebie w 1966 r. motu proprio Ecclesiae Sanctae kapituł generalnych zwyczajnych lub nadzwyczajnych, zwanych specjalnymi. Cel jednych i drugich był jednakowy - odnowa życia i struktur zakonnych oraz odpowiednie przystosowanie ich do współczesności. Kapitułom tym przyznano po raz pierwszy prawo dokonywania zmian w konstytucjach, przy założeniu, że jest to władza udzielona jedynie na pewien czas, a ewentualne zmiany dokonane w konstytucjach wymagają zatwierdzenia przez właściwą władzę kościelną̧

\footnotetext{
${ }^{57}$ J. BeY ER, Il diritto della vita consacrata, Milano 1989, s. 262.

${ }^{58}$ Zgromadzenie Sióstr Wynagrodzicielek Najświętszego Oblicza, Konstytucje, Warszawa 1989, nr 221: „Kapituła generalna może być zwyczajna lub nadzwyczajna. Kapitułę zwyczajną zwołuje się co sześć lat, po upływie czasu pełnienia urzędu przez przełożoną generalną lub gdy ten urząd wakuje z powodu śmierci, ciężkiej choroby uniezdalniającej do pełnienia urzędu, zrzeczenia się lub złożenia z urzędu przełożonej generalnej... Kapitułę nadzwyczajną zwołuje się w celu załatwienia ważnych spraw Zgromadzenia w okresie między kapitułami generalnymi zwyczajnymi”.

${ }^{59}$ Soвór WATYKański II, Dekret o przystosowanej do wspótczesności odnowie życia zakonnego «Perfectae caritatis», nr 14, w: SовóR WATY KAŃsKi II, Konstytucje, dekrety, deklaracje. Tekst polski. Nowe tłumaczenie, Poznań 2002, s. 270 (dalej:
} 
W efekcie tych działań władza najwyższa kapituł została umocniona, a ich znaczenie poważnie wzrosło ${ }^{60}$.

Należy przy tym zwrócić uwagę na fakt, że kapituły specjalne nie mogły ograniczać się tylko do tworzenia praw i rewizji konstytucji. Pierwszoplanowy miał być ich charakter duchowy, w związku z czym określono ich główny cel - popieranie żywotności duchowej i apostolskiej członków instytutu. Wyrażały wysiłek całego instytutu, włożony w proces odnowy, w podwójnym wymiarze: wewnętrznym, w nawiązaniu do Ewangelii i ducha założycieli, oraz zewnętrznym, związanym z dążeniem do właściwego funkcjonowania w aktualnej sytuacji historycznej, społecznej i kulturalnej. Ten rodzaj kapituł nadzwyczajnych-specjalnych ma obecnie charakter historyczny ${ }^{61}$.

\section{Zadania kapituł generalnych nadzwyczajnych według Kodeksu Prawa Kanonicznego z 1983 roku}

Doświadczenie posoborowej odnowy instytucji kapituły generalnej, zarówno zwyczajnej, jak i nadzwyczajnej w życiu instytutów zakonnych zostało wyrażone przez prawodawcę kościelnego zasadniczo w kanonie $631 \mathrm{KPK} / 1983$. Treść kanonu przywołuje pierwotne, a więc przede wszystkim duchowe znaczenie kapituł z czasów początku monastycyzmu. Na wstępie kanonu przypomina się, że kapituła jest

PC); PaweŁ VI, Motu proprio Ecclesiae Sanctae (06.08.1966), w: Tenże, Charyzmat życia zakonnego. Przemówienia i dokumenty. Wybór i opracowanie A. Żuchowski, T. Sułowska, Poznań-Warszawa 1974, nr 2, 3, s. 217, (dalej: Ecclesiae Sanctae); M. Cotter, The General Chapter, s. 75, 77; V. De PAolis, La vita consacrata nella Chiesa. Edizione rivista e ampliata, s. 383; R. MCDERMOTT, Governance in religious institutes: structures of participation and representation canons 631-633, The Jurist 69 (2009), s. 443-444; B. Hinze, Practices of Dialogue in the Roman Catholic Church Aims and Obstacles, Lessons and Laments, New York: Continuum Press 2006, s. 132.

${ }^{60} \mathrm{~J}$. Torres, I capitoli. Commentario ai cann. 631-633, s. 7.

${ }^{61}$ Ecclesiae Sanctae, nr 3; G. SCARvaGlieri, Il Capitolo generale, s. 30; M. DANILUK, Encyklopedia instytutów życia konsekrowanego i stowarzyszeń życia apostolskiego, s. 172-173; J. Beyer, Primo bilancio dei Capitoli di rinnovamento, Vita Consacrata 8(1972), s. 173-177; V. MAccA, Capitolo generale speciale, Dizionario degli Istituti di Perfezione, ed. G. Pelliccia-G. Rocca, vol. II, Roma 1975, col. 179-184; A. LIPPI, I capitoli speciali: impressioni e problemi, Vita Consacrata 5(1969), s. 72-77. 
najwyższą władzą w instytucie i powinna odpowiednim składem swoich członków reprezentować cały instytut i dzięki temu stawać się prawdziwym znakiem jego jedności w miłości, jak przewidywała to Charta caritatis św. St. Hardinga. W dalszej kolejności prawodawca wylicza pięć zadań kapituły generalnej, tj.: strzeżenie dziedzictwa instytutu, popieranie zgodnej z nim odnowy odpowiednio przystosowanej do współczesności, wybór najwyższego przełożonego, załatwianie ważniejszych spraw instytutu oraz wydawanie norm, które powinni zachowywać wszyscy członkowie instytutu ${ }^{62}$.

W związku z brakiem wyróżnienia ze strony prawodawcy kapituł zwyczajnych i nadzwyczajnych trzeba przyjąć, że zadania wymienione w kan. 631 są właściwe dla obu rodzajów kapituł. To z kolei rodzi już w tym miejscu pytanie o różnice zachodzące między kapitułami zwyczajnymi i nadzwyczajnymi.

\subsection{Reprezentacja całego instytutu i prawdziwy znak jego jedności w miłości}

Kapituła generalna, także ta nadzwyczajna, powinna być odpowiednio zorganizowana co do uczestnictwa w niej zakonników, tak, aby stała się reprezentacją całego instytutu, tj. wszystkich jego członków, w nawiązaniu do praktyki znanej z historii pierwszych kapituł monastycznych, w których brali udział wszyscy mnisi klasztoru lub, jak w przypadku zakonu św. Franciszka z Asyżu, wszyscy bracia, a następnie, wraz ze wzrostem liczby braci - ich przedstawiciele. Element reprezentacji całego instytutu podkreśla się również w obowiązującym prawie powszechnym i własnym instytutów ${ }^{63}$. Według D.J. Andrésa każda kapituła dopuszczająca taki sposób wyznaczenia członków, który naruszałby jej jedność i miłość braterską, powinna być odłożona i traktowana jako antykanoniczna ${ }^{64}$. I chociaż

\footnotetext{
${ }^{62}$ KPK/1983, kan. $631 \$ 1$; M. Cotter, The General Chapter, s. 25.

${ }^{63}$ Congregazione Missionarie del s. Cuore di Giesu, Documenti e deliberazioni del capitolo Generale Straordinario, Roma 1967-1968, s. 54.

${ }^{64}$ D.J. AndRÉs, Le forme di vita consacrata. Commentario teologico-giuridico al Codice di Diritto Canonico, Roma 2014.
} 
konstytucje przepisują określone kryteria zapewniające taki wybór delegatów na kapitułę, tak aby stanowiła ona prawdziwy znak jedności instytutu w miłości, to jeżeli instytut jest jednak podzielony, wewnętrznie rozbity, prawo nie uczyni cudu i skład kapituły ukaże istniejący brak jedności, a zebranie kapitulne w tej sytuacji powinno stać się okazją do nawrócenia członków instytutu i budowania jedności ${ }^{65}$.

Mimo że kapituła generalna jest organem władzy w instytucie, zachowuje swój charakter wspólnotowy (kolegialny). Więcej, władza (wł. autorità) pochodzi od łacińskiego słowa augere, które oznacza wzrost, rozwój, dojrzewanie ${ }^{66}$. Kapituła-władza w relacji wspólnota-władza powinna być miejscem troski i udziału wszystkich zakonników w życiu wspólnotowym na wszystkich jego poziomach. Kapituła generalna nadzwyczajna zwołana w określonym celu stanowi najwyższy wyraz rozeznawania wspólnotowego, np. co do charyzmatu instytutu ${ }^{67}$.

Kapituła generalna nie jest zwykłym zebraniem osób, ma bowiem cele nadprzyrodzone. Jest to wspólnota osób konsekrowanych w Chrystusie, który współdziała z nimi dla często mało dostrzegalnego nadprzyrodzonego wzrostu danego instytutu. Od członków kapituły wymaga się wniesienia do tej relacji nadprzyrodzonych zachowań, aby ich wysiłki odznaczały się wysokim poziomem duchowym $^{68}$. Nie mogą oni w trakcie obrad kierować się zasadami parlamentaryzmu, właściwego organom władzy świeckiej. Większość w głosowaniu nie zawsze świadczy o tym, że głosujący są w prawdzie, w związku z czym należy pamiętać, że większość nie zawsze jest częścią „zdrowszą” danego gremium, zgodnie z sentencja prawną:

${ }^{65}$ V. De PAolis, La vita consacrata nella Chiesa. Edizione rivista e ampliata, s. 391.

${ }^{66}$ A. Jugan, Stownik kościelny łacińsko-polski, Warszawa 1992³ , s. 60; J. SondeL, Słownik łacińsko-polski dla prawników i historyków, Kraków 1997, s. 93.

${ }^{67}$ L.G. Martín, Capitolo. Aspetti giuridici, w: Dizionario Teologico della Vita Consacrata, dir. A.A. Rodríguez, J.M. Canals Casas, Milano 1994, s. 165.

${ }^{68}$ E.F. Pironio, Natura e finalità dei capitoli generali, Informationes SCRIS 2(1976), s. 223; Tenże, Appunti per un «Capitolo», Vita Consacrata 12(1976), s. 519. 
maior non semper sanior pars ${ }^{69}$. W czasach monastycyzmu często dochodziło do sytuacji, w których niewłaściwe decyzje kapituł klasztornych, dotyczące np. wyboru przełożonego były korygowane przez biskupa miejsca lub biskupów okolicznych ${ }^{70}$.

\subsection{Strzeżenie dziedzictwa instytutu}

Charakter duchowy, właściwy dla pierwszych kapituł poszczególnych klasztorów, powoli zanikał na rzecz przyjmowania rozwiązań o charakterze organizacyjnym i prawnym. W Normach, wydanych w 1901 roku, wraz z określeniem kapituły jako najwyższej władzy w całym instytucie ${ }^{71}$ ograniczono jednocześnie jej zadania do wyboru przełożonej najwyższej, jej radnych, sekretarki i ekonomki generalnej. W dokumencie podana też została możliwość innych kwestii podlegających obradom kapituły po uprzedniej zgodzie Stolicy Apostolskiej $^{72}$. Dopiero w dokumentach Soboru Watykańskiego II, a następnie w unormowaniach KPK/1983 z właściwą im tendencją powrotu do źródeł życia zakonnego, podjęto na nowo problematykę duchową kapituł generalnych, wyrażającą się m.in. w zobowiązaniu ich do zachowania dziedzictwa duchowego (patrimonium) instytutu, a więc myśli i zamiarów założyciela wyrażonych w prawie własnym instytutu a dotyczących natury instytutu, jego celu, charakteru, ducha i zdrowych tradycji ${ }^{73}$, obejmujących praktycznie każdą dziedzinę życia członków instytutu, od charyzmatu założycielskiego poczynając.

${ }^{69}$ J. Beyer, Il diritto della vita consacrata, s. 255-256; G. Rocca, Regime, III. Questioni partcolari, Dizionario degli Istituti di Perfezione, ed. G. Pelliccia-G. Rocca, vol. VII, Roma 1983, col. 1392.

${ }^{70}$ Benedykt z Nursji, Reguła, nr 64; J. Beyer, Il diritto della vita consacrata, s. 255-256.

${ }^{71}$ Normy, nr 203.

${ }^{72}$ Normy, nr 246; F. IANNONE, Il capitolo generale. Saggio storico-giuridico, s. 44-45.

${ }^{73}$ PC, 2; KPK/1983, kan. 578; B. SzewCzul, Troska Kościoła o zachowanie "patrimonium» przez instytuty życia konsekrowanego na podstawie dokumentów kościelnych $z$ lat 1917-1996, Warszawa 2002; TENżE, La spiritualità del capitolo generale secondo il codice di diritto canonico del 1983, Commentarium pro Religiosis et Missionariis 48(2017), s. 281-306; V. De PAOLIs, La vita consacrata nella Chiesa. Edizione rivista e ampliata, s. 393; KPK/1983, kan. 630; A. VeILlEUX, Il ruolo del Capitolo generale 
Należy podkreślić wobec tego niezwykle istotny charakter kwestii podnoszonych najczęściej w czasie kapituł nadzwyczajnych i przyjmowanych przez ich organizatorów jako palące i wymagające rozważenia w ramach oddzielnego najwyższego kolegialnego gremium instytutu, jakim jest kapituła generalna nadzwyczajna. Powstaje zatem pytanie, czy muszą być zwoływane dodatkowe kapituły nadzwyczajne poświęcone kwestiom charyzmatu instytutu, apostolatu, formacji itp., skoro mogą być one podjęte także w ramach kapituł generalnych zwyczajnych $\mathrm{z}$ wyeksponowaniem np. jednego $\mathrm{z}$ wymienionych zagadnień. Może w takim podejściu do zadań kapituł generalnych zwyczajnych przeszkadza pokutująca wśród zakonników mentalność, wyrażająca się w przekonaniu, że celem kapituł jest wybór najwyższych władz instytutu i żeby poważnie omówić inne sprawy należy zwołać kapitułę nadzwyczajną? Stąd być może wynika błędne przekonanie o konieczności zwoływania kapituł nadzwyczajnych, które podejmują sprawy związane z charyzmatem i odnową instytutu (poza tymi instytutami, w których śmierć przełożonego najwyższego lub jego niezdolność do pełnienia urzędu stanowią podstawę do zwołania kapituły nadzwyczajnej).

\subsection{Popieranie przystosowanej odnowy życia zgodnej $\mathrm{z}$ dziedzictwem instytutu}

Popieranie przystosowanej odnowy życia zakonnego czy też, jak chcą tłumacze nowego polskiego wydania dokumentów soborowych, przystosowanej do wspótczesności odnowy życia zakonnego oddaje główną zasadę Concilium Vaticanum II co do życia zakonników, zasadę wyrażoną w dekrecie Perfectae caritatis. Jednocześnie Sobór wskazał kapitułę generalną jako jeden z podstawowych środków odnowy życia zakonnego. Trzeba zauważyć, że zalecaną odnową tuż po Soborze Watykańskim II zajmowały się nie tylko kapituły generalne zwyczajne, ale i nadzwyczajne, jak to zostało wyżej omówione ${ }^{74}$.

nel processo di rifondazione di un istituto religioso, Vida Religiosa, 82 (1997) 302-312, także: http://users.skynet.be/bs775533/Armand/wri/ref-ita.htm.

${ }^{74}$ PC 2, 4; B. SzewCzul, La spiritualità del capitolo generale, s. 300-301. 
W związku z tym, że odnowy nie można przeprowadzić raz na zawsze i nie jest ona aktem jednorazowym ${ }^{75}$, jest ona zagadnieniem wciąż aktualnym i nadal realizowanym przez kapituły generalne, zarówno zwyczajne, jak i nadzwyczajne, zgodnie z zapisem w kan. 631. Należy zaznaczyć, że członkowie kapituł generalnych - niezależnie od ich rodzaju - powinni znać zasady odnowy życia zakonnego przewidziane przez Concilium Vaticanum $\mathrm{II}^{76}$.

\subsection{Wybór najwyższego przełożonego}

Wybór najwyższego przełożonego według prawa własnego niektórych instytutów zakonnych jest powodem do zwołania kapituły nadzwyczajnej. W innych instytutach natomiast zwołana $\mathrm{z}$ tego powodu kapituła generalna jest jednak kapitułą zwyczajną, mimo iż wydaje się, że sytuacja będąca przyczyną jej zwołania jest nadzwyczajna ${ }^{77}$. Można zaobserwować w prawie własnym instytutów zakonnych czy stowarzyszeń życia apostolskiego tendencję do unikania zwoływania dodatkowych kapituł w przypadku śmierci przełożonego najwyższego lub niezdolności pełnienia przez niego urzędu, niezależnie od nazwy tychże kapituł. Zamieszcza się bowiem przepis, że w przypadku śmierci przełożonego po upływie połowy jego kadencji, funkcję przełożonego najwyższego pełni jego zastępca do upływu czasu kadencji zmarłego $^{78}$. Następnie zwołuje się kapitułę zwyczajną, unikając tym samym dodatkowego zjazdu członków instytutu.

\footnotetext{
${ }^{75}$ Ecclesiae Sanctae, nr 19: „Zresztą przystosowana odnowa nie może się dokonać raz na zawsze, ale trzeba ją jakimś ciągłym sposobem przeprowadzać poprzez gorliwość zakonników oraz zapobiegliwość Kapituł i Przełożonych”, s. 216-225.

${ }^{76} \mathrm{PC} 2$.

77 J. Beyer, Il diritto della vita consacrata, s. 262; Zgromadzenie Sióstr Wynagrodzicielek Najświętszego Oblicza, Konstytucje, Warszawa 1989, nr 221.

${ }^{78}$ Stowarzyszenie Apostolstwa Katolickiego, Prawo podstawowe, nr 106, http://www.pallotyni.pl/prawo-podstawowe/rozdzial-v-82-158/artykul-2-90-148. html: „Zebranie Generalne zwyczajne zwołuje się co sześć lat - a nawet i wcześniej - jeżeli zajdzie potrzeba dokonania nowego wyboru Zarządu Generalnego; nadzwyczajne może być zwołane w każdym czasie mocą decyzji Rady Generalnej, gdy okoliczności wskazują na taką konieczność, albo też na żądanie absolutnej większości rad prowincjalnych i regionalnych”. Tamże nr 134. „Przypadek wakansu.
} 


\subsection{Załatwianie ważniejszych spraw instytutu}

Zapis kanonu $631 \S 1$ o podejmowaniu przez kapitułę generalną ważniejszych spraw instytutu daje zazwyczaj podstawy do zwołania w instytucie kapituły generalnej nadzwyczajnej. Za główny przedmiot zgromadzenia kapitulnego przyjmuje się najczęściej - jako ważną sprawę - jakieś zagadnienie związane z odnową życia zakonnego, poświęcając mu całość obrad kapitulnych. Najczęstszym motywem zwołania kapituły jest dokonanie rewizji prawa własnego i zatwierdzenie nowej redakcji konstytucji oraz zbiorów drugorzędnych ${ }^{79}$ albo też przyjrzenie się formacji zakonników, działalności apostolskiej instytutu, jego charyzmatowi, sprawowaniu władzy, sprawom materialnym oraz życiu braterskiemu we wspólnocie celem jego polepszenia ${ }^{80}$ itp.

\subsection{Wydawanie norm prawnych}

Każda kapituła generalna, a więc i ta nadzwyczajna, kończy się podjęciem decyzji ujętych w odpowiednie dla danego instytutu normy prawne. Normy te służą rozwiązaniu dyskutowanych w czasie kapituły kwestii. Normy prawne kryją w sobie zapisy związane ostatecznie z patrimonium duchowym instytutu, a więc mają one charakter duchowy ${ }^{81}$. Dzięki nim dziedzictwo duchowe, pozostawione przez założyciela instytutu, może trwać przez wieki w członkach instytutu i w Kościele.

Wybory w okresie sześciolecia. Jeżeli podczas pierwszych trzech lat sześcioletniej kadencji nastąpi wakat funkcji Przełożonego Generalnego, zastąpi go jako wikariusz Pierwszy Radca, który natychmiast zatroszczy się o zwołanie zwyczajnego Zebrania Generalnego. Jeżeli natomiast wakat będzie miał miejsce w drugim trzechleciu, zastąpi go jako wikariusz Pierwszy Radca aż do końca tego sześciolecia”.

${ }^{79}$ XXVI Nadzwyczajna Kapituła Generalna Zgromadzenia Sióstr św. Dominika, https://dominikanki.pl/xxvi-nadzwyczajna-kapitula-generalna/l; Kapituła nadzwyczajna prowincji św. Maksymiliana Marii Kolbego Braci Mniejszych Konwentualnych, https://www.franciszkanie.gdansk.pl/2018/11/06/kapitula-nadzwyczajna-2018-dzien-2/; Zgromadzenie Sióstr Matki Bożej Miłosierdzia, https:// www.faustyna.pl/zmbm/nadzwyczajna-kapitula-generalna.

${ }^{80}$ Kapucyni: Kapituła nadzwyczajna rozpoczęta http://www.zyciezakonne.pl/ wiadomosci/kraj/kapucyni-kapitula-nadzwyczajna-rozpoczeta-33462.

${ }^{81}$ F. IANONE, Il capitolo generale, s. 88. 


\section{Opinie kanonistów dotyczące kapituł nadzwyczajnych}

Pierwsze kapituły generalne zwołane w instytutach zakonnych po wcześniejszej serii częstych posoborowych kapituł specjalnych i zatwierdzonych w efekcie ich działania licznych norm prawnych, zastały instytuty obciążone całym pokapitulnym doświadczeniem przeprowadzania wzmożonej odnowy życia. Kapituły posoborowe - jeżeli wcześniej zaproponowane nazbyt liczne zmiany nie zostały wprowadzone w życie - prowadziły do ryzyka postrzegania kolejnych kapituł generalnych, zwoływanych w trybie przepisanym przez konstytucje, jako znaku zastoju i stagnacji, a nawet cofnięcia się prowadzącego do rozpadu instytutu ${ }^{82}$. Poza tym nader częste zwoływanie kapituł generalnych w instytucie utwierdzało jego członków w fałszywym przekonaniu, że życie zakonne zależy od niemal permanentnego działania kapituły generalnej ${ }^{83}$. Wydaje się, że to przeświadczenie funkcjonuje w życiu zakonnym także obecnie. Zwoływanie kapituł nadzwyczajnych między kapitułami zwyczajnymi czy też rozczłonkowywanie tych ostatnich na kilka sesji zwoływanych w krótkich odstępach czasu może przyczynić się do powstania podobnej świadomości wśród członków instytutu, a w efekcie - do ograniczenia władzy przełożonego generalnego i jego rady.

Kapituła generalna nie jest instytucją permanentną, a częste jej zwoływanie stoi w sprzeczności z unormowaniem KPK/1983 ${ }^{84}$. Co więcej, zmienia się wówczas tożsamość instytutu, który z pełnej mobilności apostolskiej przekształca się w „konwentualny”, podczas gdy kapituła spełnia rolę tymczasowej rady generalnej, czyniąc ją nazbyt zależną od dyskusji kapitulnych, podczas których zresztą niektóre sprawy, jak np. personalne, nie mogą być rozpatrywane ${ }^{85}$. Abstrahując od obowiązujących norm prawnych, należy zauważyć, że już sama roztropność nie radzi częstego zwoływania kapituł, przede wszystkim

\footnotetext{
${ }^{82}$ A. Zigrossi, Il capitolo è di nuovo alla porta, Consacrazione e Servizio 23(1974) s. 32 .

${ }^{83}$ E.F. Pironio, Natura e finalità dei capitoli generali, s. 217.

${ }^{84} \mathrm{KPK} / 1983$, kan. 632.

${ }^{85} \mathrm{~J}$. BEYER, Il diritto della vita consacrata, s. 263.
} 
z powodu wydatków związanych z przybyciem członków kapituły na miejsce obrad i konieczności przerwania przez nich swej zwyczajnej działalności. Poza tym atmosfera przedkapitulna w instytucie i podczas trwania kapituły powoduje niekorzystne, przesadne skierowanie uwagi członków całego instytutu przez dłuższy czas na niektóre sprawy, wzbudza wątpliwości, niepewność, niepotrzebne dyskusje i naciski ${ }^{86}$. Stąd w konstytucjach Towarzystwa Jezusowego zamieszczony został przepis o ograniczeniu odbywania kongregacji generalnych, które są kłopotliwe i wiążą się z wysiłkiem całego Towarzystwa, na rzecz władzy przełożonego generalnego złączonego z całym Towarzystwem i wspieranego pomocą swych współpracowników ${ }^{87}$.

Nadmiernie częste zwoływanie kapituł powoduje, że coraz więcej spraw pozostawionych im do rozstrzygnięcia nabiera rangi ważnych, co tworzy wrażenie, że członkowie instytutu muszą oczekiwać rozstrzygnięcia sprawy przez kapitułę, bo władza przełożonego generalnego i jego rady już nie wystarcza.

\section{Zakończenie}

W literaturze kanonistycznej niezmiernie rzadko spotyka się publikacje dotyczące stricte kapituł nadzwyczajnych. W tych dostępnych, ujętych w niniejszym artykule, podaje się uzasadnione powody do ich zwołania, ale też ostrzega się przed nadmiernym korzystaniem z tej formy sprawowania władzy w instytucie. Głównym przeciwwskazaniem jest ryzyko wydawania w nadmiernej ilości norm prawnych czy całych dokumentów kapitulnych, które, kumulowane,

\footnotetext{
${ }^{86}$ Tamże.

${ }^{87}$ Konstytucje Towarzystwa Jezusowego wraz z przypisami Kongregacji Generalnej XXXIV oraz normy uzupetniające zatwierdzone przez tę sama Kongregacje, nr [667], Kraków-Warszawa 2006, s. 233: „...trzeba przede wszystkim stwierdzić, że w obecnym stanie rzeczy nie wydaje się w Panu wskazane, $[A]$ żeby odbywała się ona [kongregacja generalna - B. Sz.] w ustalonych terminach lub często, ponieważ Przełożony Generalny, $[B]$ dzięki łączności z całym Towarzystwem i wspierany wysiłkiem tych, którzy z nim przebywają, oszczędzi w miarę możliwości tego trudu i kłopotu całemu Towarzystwu”.
} 
rzadko są czytane przez członków instytutu i w niewielkim stopniu zachowywane ${ }^{88}$.

W ramach konkluzji warto odwołać się też do zasady zawartej w soborowym dekrecie Perfectae caritatis, stwierdzającej, że odnowa życia w instytucie nie zależy od ciągłego formułowania nowych przepisów, lecz od ich wiernego przestrzegania ${ }^{89}$. W przepisach wykonawczych do wspomnianego dekretu, ujętych w motu proprio Ecclesiae Sanctae, dodaje się, że w procesie odnowy czymś pierwszoplanowym jest, zarówno ze strony przełożonych, jak i podwładnych, odnowienie życia zakonnego przede wszystkim w sobie samych, a odnośnie do kapituł ważne jest przygotowanie ducha kapituł, a nie samo przegłosowywanie uregulowań prawnych czy wybór władz instytutu ${ }^{90}$.

\section{Meaning of extraordinary general chapters in religious institutes}

In relations to a an increasingly frequent convocations of general chapters in religious institutes of consecrated life, authoress took up a problem: if it is proper to take an excessive advantage of that institution? We expect, that participants of the extraordinary chapters will find proper ways of the renewal of religious life, solution of difficulties, and recovery from stagnation, and even - institute refound. It seems, that the meaning of the extraordinary chapters is frequently overestimated, expectations are too high and they are treated as very efficient and immediate antidote for problems existing in religious life, as well as for long-lasting negligence, wrong decisions, or their lack, performed by competent authority of the institute.

\footnotetext{
${ }^{88}$ J. Torres, I capitoli. Commentario ai cann. 631-633, s. 29.

${ }^{89}$ PC 4: „Niech wszakże wszyscy pamiętają, że nadzieję odnowy należy pokładać raczej w dokładniejszym przestrzeganiu reguły i konstytucji aniżeli w mnożeniu przepisów"

90 Ecclesiae Sanctae I, nr 2: „Konieczna jest współpraca wszystkich Przełożonych i zakonników do odnowienia życia zakonnego w sobie samych do przygotowania ducha kapituł, do przeprowadzenia ich dzieła, do wiernego przestrzegania ustaw i przepisów, uchwalonych przez kapituły".
} 
Main contraindication related to the excessive using of that form of performing authority in the institute is a hasty convening of such chapters, risk of issuing too large number of the judiciary norms, or even the whole chapter's documents, which, when cumulated, are very rarely read by institute members, and only few are saved.

On the other hand the pre-chapter atmosphere in the institute, and during the chapter, brings about unfavourable, excessive, and long-term concentration of the members of the institute on certain matters, stirs up doubts, insecurity, needless discussions and pressure.

Arrival of the chapter members to the place of proceedings - quite often from a distant countries - is connected with additional costs and a necessity of disruption of an institute everyday activities.

SŁowA KLUCzowe: kapituła generalna; kapituła nadzwyczajna; instytut zakonny; dziedzictwo instytutu

KEYwORDS: general chapter; extraordinary chapter; religious institute; patrimony of the institute

\section{Nota O AUTORCE}

S. Dr hab. Bożena Szewczul, Prof. uCzelni - pracownik naukowo-dydaktyczny na Wydziale Prawa Kanonicznego UKSW w Warszawie, kierownik zakładu Kanonicznych Form Życia Konsekrowanego w Katedrze Ustroju Kościoła i Kanonicznych Form Życia Konsekrowanego. 